\title{
PENGUJIAN KONSTRUK TES POTENSI MANAJERIAL BERDASARKAN VALIDITAS BUTIR DENGAN METODE FACTOR ANALYSIS
}

\author{
Rita Markus Idulfilastri ${ }^{1}$ \\ ${ }^{1}$ Fakultas Psikologi, Universitas Tarumanagara \\ Email: ritamarkus@fpsi.untar.ac.id
}

\begin{abstract}
ABSTRAK
Tes Potensi Manajerial merupakan tes psikologi mengukur potensi manajerial dalam ranah kognitif berdasarkan konsep Differentiated Model of Giftedness and Talent (DMGT) yaitu terjadinya proses transformasi potensi menjadi talenta. Tujuan penelitian adalah menguji konstruk tes potensi manajerial yaitu konstruk kognitif, metakognitif dan kreativitas berdasarkan validitas butir menggunakan factor analysis, Confirmatory Factor Analysis (CFA). Jumlah butir tes sebanyak 80 butir, pengambilan data pada sampel di industri otomotif level manajerial Supervisor, Asisten Manager dan Manager berjumlah 181 subyek. Mengingat adanya penambahan butir menjadi 80 butir, dilakukan kategorisasi faktor sebagai uji pendahuluan menggunakan Exploratory Factor Analysis (EFA). Pengolahan data CFA menggunakan program Lisrel version 8.80, hasil pengujian berdasarkan model fit dan butir validi dengan Pvalue > 0,05; factor loading positif; $t$-value >1,96. Diperoleh hasil 11 indikator dengan jumlah 50 butir valid pada 3 konstruk. Konstruk kognitif terdiri 3 indikator, asumsi, deduktif dan interpretasi, jumlah 17 butir valid; konstruk metakognitif terdiri 5 indikator, deklarasi, kondisi, strategi, pengawasan, evaluasi, jumlah 16 butir valid dan konstruk kreativitas terdiri 3 indikator, fleksibelitas, keberanian berbeda dan spontanitas, jumlah 17 butir valid. Kesimpulan Tes Potensi Manajerial dapat dipakai di industri otomotif menggunakan 11 indikator dan 50 butir valid. Adanya perbedaan komposisi indikator dan jumlah butir yang dihasilkan dibandingkan penelitian sebelumnya sebagai indikasi tipe bisnis atau industri berbeda membutuhkan karakteristik Tes Potensi Manajerial spesifik.
\end{abstract}

Kata kunci: potensi manajerial, validitas butir, factor analysis

\section{PENDAHULUAN}

\section{Tes Potensi Manajerial}

Tes Potensi Manajerial merupakan tes psikologi yang mengukur potensi manajerial dalam ranah kognitif dan tergolong sebagai tes prediktif kinerja manajerial (Idulfilastri, 2012). Gagne (2008) dengan konsep Differentiated Model of Giftedness and Talent (DMGT) menjelaskan bahwa pada dasarnya setiap manusia mempuyai bakat, disebut sebagai potensi alami yang bertransformasi menjadi talenta (talent), disebut potensi yang diwujudkan sebagai kemampuan. Proses terjadinya transformasi ini melalui kegiatan belajar maupun pengalaman praktis. Gagne (2008) juga menjelaskan potensi alami yaitu kecerdasan, kreativitas, sosialisasi dan fisik, sedangkan talenta dapat dilihat dari kemampuan akademik, kemampuan seni, kemampuan bisnis, kemampuan berhubungan dengan kesenangan, kemampuan kegiatan sosial dan kemampuan teknologi. Atas kajian pustaka (Idulfilastri, 2012) diperoleh hasil potensi manajerial sebagai potensi alami dibangun oleh 3 (tiga) dimensi sebagai konstruk laten, yaitu kognitif, metakognitif dan kreativitas. Potensi manajerial dapat memprediksi kompetensi, yaitu kemampuan pemecahan masalah dan pengambilan keputusan, kemampuan pencapaian target kerja, kemampuan menyampaikan gagasan. Dengan diketahuinya potensi manajerial diharapkan dapat diantisipasi kemungkinan keberhasilan karir.

Pembahasan kognitif dapat dikaitkan dengan pemrosesan informasi. Namun penelitian ini mengkaitkan kemampuan kognitif dengan pendekatan berpikir kritis (Watson \& Glaser, 2008), 
dikatakan berpikir kritis adalah suatu proses berpikir dengan membuat asumsi-asumsi tertentu, mereflesikan pikiran, melakukan analisis sintesa, melakukan evaluasi dan melihat hubungan logika. Watson \& Glaser (2008) memperdalam bahwa asumsi-asumsi selalu dipertanyakan supaya dapat memutuskan dengan benar, melakukan refleksi terhadap pikiran-pikiran sendiri agar memahami dan meyakini suatu hal dengan tepat, melakukan analisis sintesis dan evaluasi terhadap informasi serta melakukan penalaran terhadap semua informasi agar dapat dikomunikasikan dengan tepat. Metakognitif merupakan proses berpikir untuk melakukan pengontrolan aktif terhadap pembelajaran, baik dalam kegiatan manajemen maupun strategik (Knutson, 2014). Seorang yang memiliki kreativitas dicirikan sebagai individu yang selalu bertanya mengenai latar belakang terjadinya suatu keadaan, individu yang memperbolehkan terjadinya kesalahan dalam bertindak, individu yang sensitif terhadap perhitungan risiko, individu yang selalu mencari tugastugas berbeda dan baru, individu yang aktif mencari akar suatu masalah dan individu yang berpikir ulang kemungkinan suatu masalah terjadi kembali.

Pengembangan tes berawal dari pertanyaan mengenai darimanakah munculnya kompetensi? Apakah dari hasil proses belajar atau bakat yang dipunyai sejak lahir? Berdasarkan kajian pustaka (Idulfilastri, 2012) telah diperoleh tes potensi manajerial terdiri dari tiga dimensi yaitu dimensi kognitif, dimensi metakognitif dan dimensi kreativitas terdiri 14 indikator dan 105 item. Pengujian dengan sampel subyek sebanyak 322 orang di posisi manajerial dari tipe bisnis jasa keuangan, konstruksi, konsultan IT, industri dan distributor. Pengujian menggunakan CFA second order dengan estimate true score untuk memperkecil kesalahan skor amatan. Hasil psikometerik terhadap seluruh butir diperoleh $\chi^{2}=722.05, d f=64, P$-value $=0.5857, R M S E A=0.017$; dimensi kognitif $\quad \chi^{2}=117.75, \quad d f=95, \quad P$-value $=0.06, \quad R M S E A=0.027$ dimensi metakognitif $\chi^{2}=116.92, d f=93, P$-value $=0.05, R M S E A=0.028$ telah teruji bahwa data empiris fit terhadap konsep teoritis dan diperoleh hasil dimensi kognitif terdiri 5 indikator, 19 butir valid dan dimensi metakognitif terdiri 8 indikator, 16 butir valid. Sedangkan dimensi kreativitas tidak terbukti sebagai dimensi tes potensi manajerial (Idulfilastri, 2012).

Mengingat belum terbuktinya dimensi kreativitas dan dalam rangka pengembangan tes dengan maksud pemutahiran butir tes (Sijtsma, 2009) maka butir tes ditambah menjadi 80 butir terdiri dari 25 butir dimensi kognitif, 32 butir dimensi metakognitif dan 23 butir dimensi kreativitas. Adanya penambahan butir maka perlu dikaji ulang mengenai validitas konstruk berdasarkan validitas butir. Inilah sebagai tujuan penelitian yaitu menguji validitas konstruk tes potensi manajerial berdasarkan validitas butir. Hasil pengujian berupa butir-butir valid yang membangun konstruk laten dan squared multiple correlation yaitu konstribusi butir item terhadap konstruk latennya (Kaplan, 2009; Hashmi, Zeeshan, Saleem \& Akbar, 2012).

\section{Validitas butir}

Sesuai dengan tujuan, pengujian validitas butir menjadi penting karena konstruk atau indikator diukur secara tidak langsung. Validitas butir sebagai manifestasi validitas kontruk, apakah butir tes dapat dijadikan alat ukur. Manifestasi ini oleh Cohen \& Swerdlik (2013) dihitung dengan indeks validitas butir, seberapa besar tes mengukur sesuai dengan tujuan pengukuran, dihitung berdasarkan simpangan baku skor butir dan korelasi skor butir dan skor kriteria. Sedangkan menurut Hair, J.F., Black, W.C., Babin, B.J., Anderson, R.E., Tatham, R.L. (2006) validitas butir dihitung melalui validitas diskriminan, sejauh mana sebuah konstruk benar-benar berbeda dari konstruk lainnya.

Pengujian validitas butir menggunakan Confirmatory Factor Analysis (CFA) yaitu model pengukuran dari Structural Equation Modelling (SEM). SEM menekankan penggunaan kovarian 
yaitu meminumkan perbedaan antara kovarian sampel dengan kovarian yang diprediksi oleh model yang dikonsepkan. Model pengukuran CFA merupakan hubungan refleksi dari variabelvariabel teramati terhadap variabel latennya. Model pengukuran mengkonfirmasikan apakah variabel-variabel teramati merupakan butir yang mereflesikan variabel latennya (Wijanto, 2008). Dengan demikian, konsep validitas butir pada penelitian ini mengacu pada konsep besarnya loading factor butir terhadap konstruk sebagai variabel laten.

Sehubungan validitas butir dan validitas diskriminan bersifat redundansi (Panjaitan, 2018), ternyata dengan menggunakan CFA, sifat redundansi dapat diatasi. Menurut Hair, et al. (2006) dengan CFA dapat dilakukan pengujian terhadap butir tes yang merefleksikan konstruk laten dan kemudian dilakukan pengujian terhadap konstruk-konstruk lainnya. Berdasarkan square of the correlation estimate antara dua konstruk dapat dibandingkan. Jika variarince-extracted estimate lebih besar daripada squared correlation estimate, dapat dikatakan konstruk laten yang diukur oleh butir tes lebih baik dibandingkan konstruk-konstruk lainnya.

\section{METODE PENELITIAN}

\section{Karakteristik partisipan}

Partisipan berasal dari karyawan industri otomotif, memproduksi motor dan mobil buatan Jepang di perusahaan X. Jumlah seluruh partisipan 181 orang di level manajerial, dipromosikan sebagai Supervisor sebanyak 100 orang, sebagai Asisten Manager sebanyak 43 orang dan sebagai Manager sebanyak 38 orang. Pengambilan sampel menggunakan teknik purposive sampling yaitu pengambilan sampel berdasarkan pertimbangan sudah mampu menduduki posisi manajerial atau mampu menduduki posisi manajerial di tingkat lebih tinggi. Posisi manajerial yang dimaksud yaitu posisi Supervisor, Asisten Manager dan Manager (Furr \& Bacharach, 2014). Jumlah sampel sudah memenuhi persyaratan minimal yaitu lebih dari 100 subyek (Wijanto, 2008).

\section{Pengukuran}

Berdasarkan konstruksi tes psikologi, Tes Potensi Manajerial tergolong tes potensi (aptitude test), psychological testing, bersifat power test dan pilihan jawaban benar atau salah (Kaplan \& Saccuzzo, 2001; Cohen \& Swerdlik, 2005; Mankar \& Chavan, 2013). Definisi operasional dimensi kognitif adalah kemampuan memproses berpikir sehingga mampu menghasilkan pemikiranpemikiran kritis dalam usaha untuk memecahkan masalah dan mengambil keputusan. Definisi operasional dimensi metakognitif adalah kemampuan memproses berpikir yang melibatkan kesadaran metakognitif dan regulasi metakognitif dalam kegiatan manajemen dan kegiatan strategik. Definisi operasional kreativitas adalah kemampuan individu untuk berani berbeda dengan orang lain dalam menciptakan atau menuangkan gagasan (Wigboldus \& Dotsch, 2016).

Dimensi kognitif dibangun oleh 5 indikator yaitu inferensi, asumsi, deduksi, interpretasi dan evaluasi argumen. Jumlah butir sebanyak 25 butir dijawab dengan memilih benar dan salah sesuai dengan cerita atau pernyataan yang diberikan. Contoh soal 1, "Cerita: Pada hari Kemerdekaan RI, banyak pejuang yang menghadiri upacara pengibaran bendera merah putih. Bila dilihat dari peserta yang hadir ternyata banyak yang berusia lanjut. Kemungkinan di antara mereka ada yang mengikuti langsung peristiwa kemerdekaan pada tahun 1945. Butir pertanyaan: Upacara pengibaran bendera merah putih dilaksanakan di Istana Negara RI". Jawaban benar atau salah". Contoh soal 2, "Pernyataan: Pada hari Senin banyak pekerja berangkat lebih pagi dibandingkan hari lainnya. Butir pertanyaan: Pada hari Senin pagi, lalu lintas lebih macet dibandingkan hari-hari lainnya". Jawaban benar atau salah". 
Dimensi metakognitif terdiri dari 8 indikator yaitu deklarasi, prosedur, kondisi, perencanaan, strategi, pengawasan, perbaikan strategi dan evaluasi. Jumlah butir sebanyak 32 dan butir dijawab dengan memilih pernyataan a atau b yang paling menggambarkan diri partisipan. Contoh butir 1: "a. Handal mengatur informasi b. Handal menyimpan informasi. Jawaban a atau b". Contoh butir 2: "a. Menunggu sampai berakhirnya proses, baru diubah. b. Mengubah strategi segera ketika berlangsungnya proses. Jawaban a atau b".

Dimensi kreativitas tidak ada indikator. Jumlah butir sebanyak 23 dan butir dijawab dengan memilih pernyataan $\mathrm{a}, \mathrm{b}$ atau c yang paling menggambarkan diri partisipan. Contoh butir 1:" a. Hati-hati b. Fleksibel c. Disiplin. Jawaban a, b atau c". Contoh butir 2: "a. Pandai tapi malas, b. Pandai tapi berbohong, c. Pandai tapi nakal. Jawaban a, b atau c”.

Pengujian pendahuluan dilakukan dengan mereduksi butir berdasarkan faktor (Hair, et al., 2006; Young \& Pearce, 2013; Tarka, 2018). Teknik pengujian menggunakan Exploratory Factor Analysis (EFA) dengan program aplikasi IBM SPSS Statistics version 22. Metode ekstrasi butir menggunakan Maximum Likelihood, metode rotasi dengan Varimax, penetapan jumlah faktor yang diekstrak (extracting factors) sesuai dengan jumlah indikator dan dilakukan iterasi maksimum sebanyak 25 kali. Hasil pengujian dalam bentuk Rotated Factor Matrix yang menunjukkan korelasi antar butir di setiap faktor.

Teknik pengujian validitas butir menggunakan metoda Confimatory Factor Analysis (CFA) dengan program statistik LISREL version 8.80. Sesuai dengan model pengukuran di dalam SEM (Sructural Equation Modelling) maka perlu dicapai model fit dengan P-value > 0,05 artinya data empirik sesuai dengan model yang dikonsepkan. Hasil pengujian dikatakan sebagai butir valid jika butir mempunyai faktor loading positif, $t$-value $>1,96$ pada tingkat level of confidence $95 \%$ (Kaplan, 2009).

\section{HASIL DAN PEMBAHASAN}

Hasil pengujian pendahuluan berdasarkan pengelompokkan faktor diperoleh hasil konstruk kognitif dengan 5 indikator dan dibangun oleh 23 butir, konstruk metakognitif terdiri dari 2 bagian, yaitu bagian mengelola masalah dan bagian mengelola strategik dengan jumlah 29 butir dan konstruk kreativitas menghasilkan 3 indikator fleksibelitas, berani berbeda dan spontanitas dengan jumlah 17 butir.

Hasil pengujian EFA menghasilkan butir-butir berkorelasi tinggi di indikator yang membangunnya (Hair, et al., 2006; Kelloy, 2005). Oleh karena itu perlu dilanjutkan dengan pengujian butir valid terhadap indikator dan konstruk menggunakan Confirmatory Factor Analysis (Maat, Adnan, Abdullah, Ahmad, Puteh, 2015).

\section{Pengujian Konstruk Metode Confirmatory Factor Analysis (CFA)}

Hasil pengujian konstruk kognitif dengan metode CFA diperoleh 3 indikator, yaitu asumsi, deduktif dan interpretasi dengan jumlah 17 butir valid (model fit pada $P$-value $>0,05$; factor loading positif; $t$-value $>1,96$. Lihat Tabel 1 .

Tabel 1.

Hasil Pengujian Konstruk Kognitif dengan Indikator Valid Metode CFA

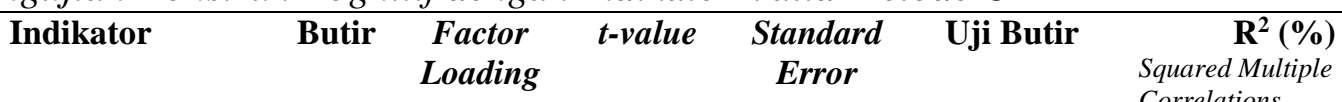




\begin{tabular}{|c|c|c|c|c|c|c|}
\hline \multirow{6}{*}{$\begin{array}{c}\text { Asumsi } \\
\text { P-value }=0,334 ; \\
\chi 2=9,09 ; \\
\text { RMSEA }=0,028\end{array}$} & K2 & 0,48 & 5,96 & 0.08 & Valid & 23 \\
\hline & K6 & 0,45 & 5,11 & 0,09 & Valid & 20 \\
\hline & K9 & 0,23 & 2,72 & 0,08 & Valid & 5 \\
\hline & K10 & 0,78 & 9,17 & 0,09 & Valid & 61 \\
\hline & K13 & 0,27 & 3,24 & 0.08 & Valid & 7 \\
\hline & K19 & 0,52 & 5,99 & 0,09 & Valid & 27 \\
\hline \multirow{5}{*}{$\begin{array}{c}\text { Deduktif } \\
\text { P-value }=0,165 ; \\
\chi 2=5,10 ; \\
\text { RMSEA }=0,062\end{array}$} & $\mathrm{~K} 4$ & 0,36 & 4,12 & 0,09 & Valid & 13 \\
\hline & K11 & 0,23 & 2,55 & 0,09 & Valid & 5 \\
\hline & K15 & 0,19 & 2,17 & 0,09 & Valid & 4 \\
\hline & K21 & 0,66 & 6,56 & 0,10 & Valid & 44 \\
\hline & K24 & 0,76 & 6,99 & 0,11 & Valid & 56 \\
\hline \multirow{6}{*}{$\begin{array}{c}\text { Interpretasi } \\
\text { P-value }=1,367 \\
\chi 2=0,00 ; \\
\text { RMSEA }=0,000\end{array}$} & K3 & 0,72 & 7,42 & 0,10 & Valid & 50 \\
\hline & K17 & 0,53 & 5,85 & 0,09 & Valid & 3 \\
\hline & K18 & 0,38 & 4,18 & 0,09 & Valid & 25 \\
\hline & K20 & 0,32 & 3,51 & 0,09 & Valid & 12 \\
\hline & K23 & 0,34 & 3,75 & 0,09 & Valid & 9 \\
\hline & K25 & 0,42 & 4,68 & 0,09 & Valid & 25 \\
\hline
\end{tabular}

Jika ditinjau dari struktur butir ternyata K9, K11, K13, K15 dengan loading factor < 0,30 merupakan butir yang kontradiktif dengan kehidupan nyata. Contoh butir K13, Keputusan yang sulit dibuat oleh pemimpin yang bertanggung jawab. Sedangkan butir-butir lainnya, merupakan butir dalam kehidupan nyata. Contoh butir K10, Di dalam tubuh bugar dapat menghasilkan produktifitas kerja yang tinggi.

Jika ditinjau dari konstribusi butir terhadap indikator, terlihat butir K10, K24, K3, dengan $\mathrm{R}^{2}=61 \%, 56 \%, 50 \%$ merupakan butir dengan konstribusi paling besar terhadap indikator asumsi, deduksi dan interpretasi.

Hasil pengujian konstruk metakognitif metode CFA diperoleh 5 indikator, yaitu deklarasi, kondisi, strategi, pengawasan, evaluasi dengan jumlah 16 butir valid (model fit pada P-value>0,05; factor loading positif; $t$-value $>1,96$ ). Lihat Tabel 2. 
Tabel 2.

Hasil Pengujian Konstruk Metakognitif dengan Indikator Valid Metode CFA

\begin{tabular}{|c|c|c|c|c|c|c|}
\hline Indikator & Butir & $\begin{array}{c}\text { Factor } \\
\text { Loading }\end{array}$ & $t$-value & $\begin{array}{c}\text { Standard } \\
\text { Error }\end{array}$ & Uji Butir & $\begin{array}{c}\mathbf{R}^{\mathbf{2}} \\
\text { Squared Multiple } \\
\text { Correlations } \\
\end{array}$ \\
\hline \multirow{3}{*}{$\begin{array}{c}\text { Deklarasi } \\
\text { P-value }=1,000 ; \\
\chi 2=0,00 ; \text { RMSEA }=0,000\end{array}$} & M4 & 0,43 & 4,61 & 0,09 & Valid & 19 \\
\hline & M5 & 0,77 & 6,14 & 0,13 & Valid & 60 \\
\hline & M9 & 0,55 & 5,32 & 0,10 & Valid & 31 \\
\hline \multirow{3}{*}{$\begin{array}{c}\text { Kondisi } \\
\text { P-value }=1,000 ; \\
\chi 2=0,00 ; \text { RMSEA }=0,000\end{array}$} & M1 & 0,84 & 3,13 & 0,27 & Valid & 70 \\
\hline & M3 & 0,33 & 2,63 & 0,13 & Valid & 11 \\
\hline & M10 & 0,34 & 2,64 & 0,13 & Valid & 11 \\
\hline \multirow{3}{*}{$\begin{array}{c}\text { Strategi } \\
\text { P-value }=1,000 ; \\
\chi 2=0,00 ; \text { RMSEA }=0,000\end{array}$} & M16 & 0,55 & 4,37 & 0,13 & Valid & 31 \\
\hline & M24 & 0,45 & 4,02 & 0,11 & Valid & 20 \\
\hline & M29 & 0,51 & 4,25 & 0,12 & Valid & 26 \\
\hline \multirow{3}{*}{$\begin{array}{c}\text { Pengawasan } \\
\text { P-value }=1,000 ; \\
\chi 2=0,00 ; \text { RMSEA }=0,000\end{array}$} & M14 & 0,95 & 13,65 & 0,07 & Valid & 91 \\
\hline & M25 & 0,83 & 11,66 & 0,07 & Valid & 69 \\
\hline & M30 & 0,53 & 7,28 & 0,07 & Valid & 28 \\
\hline \multirow{4}{*}{$\begin{array}{c}\text { Evaluasi } \\
\text { P-value }=0,597 ; \\
\chi^{2}=1,03 ; \text { RMSEA }=0,000\end{array}$} & M15 & 0,33 & 3,62 & 0,09 & Valid & 11 \\
\hline & M17 & 0,93 & 5,86 & 0,16 & Valid & 87 \\
\hline & M22 & 0,26 & 3,03 & 0,09 & Valid & 7 \\
\hline & M23 & 0,45 & 4,46 & 0,10 & Valid & 20 \\
\hline
\end{tabular}

Jika ditinjau dari struktur butir ternyata M22 dengan loading factor $<0,30$ merupakan butir pertanyaan untuk langkah tindak lanjut. Contoh butir M22, (a) Pekerjaan selesai, bertanya: Adakah cara lebih mudah? (b) Pekerjaan selesai, bertanya: Adakah pekerjaan lain? Sedangkan butir-butir lainnya, merupakan butir pernyataan, bukan butir pertanyaan. Contoh M14, (a) Memahami makna dari informasi baru. (b) Tetap bertahan dengan informasi lama.

Jika ditinjau dari konstribusi butir terhadap indikator, terlihat butir M5, M1, M16, M14, M17 dengan $\mathrm{R}^{2}=60 \%, 70 \%, 31 \%, 91 \%, 87 \%$ merupakan butir dengan konstribusi paling besar terhadap indikator deklarasi, kondisi, strategi, pengawasan, evaluasi.

Hasil pengujian konstruk kreativitas dengan CFA diperoleh 3 indikator jumlah 17 butir valid (model fit pada P-value >0,05; factor loading positif; $t$-value $>1,96$ ). Lihat tabel 3. 
Tabel 3.

Hasil Pengujian Konstruk Kreativitas Metode Confirmatory Factor Analysis (CFA)

\begin{tabular}{|c|c|c|c|c|c|c|}
\hline Indikator & Butir & $\begin{array}{c}\text { Factor } \\
\text { Loading }\end{array}$ & t-value & $\begin{array}{c}\text { Standard } \\
\text { Error }\end{array}$ & Uji Butir & $\begin{array}{c}\mathbf{R}^{\mathbf{2}} \\
\text { Squared } \\
\text { Multiple } \\
\text { Correlations } \\
\end{array}$ \\
\hline \multirow{4}{*}{$\begin{array}{c}\text { Fleksibilitas } \\
\text { P-value }=1,000 ; \\
\chi 2=0,00 ; \text { RMSEA }=0,000\end{array}$} & $\mathrm{P} 2$ & 1,00 & 18,43 & 0,06 & Valid & 100 \\
\hline & $\mathrm{P} 4$ & 0,60 & 8,67 & 0,07 & Valid & 36 \\
\hline & P15 & 0,79 & 12,19 & 0,06 & Valid & 62 \\
\hline & $\mathrm{P} 20$ & 0,90 & 14,88 & 0,06 & Valid & 81 \\
\hline \multirow{6}{*}{$\begin{array}{c}\text { Keberanian berbeda } \\
\text { P-value }=0,084 ; \\
\chi 2=11,13 ; \text { RMSEA }=0,069\end{array}$} & P3 & 0,47 & 7,34 & 0,07 & Valid & 22 \\
\hline & P6 & 1,00 & 23,78 & 0,05 & Valid & 100 \\
\hline & P9 & 0,32 & 5,45 & 0,06 & Valid & 10 \\
\hline & P12 & 0,15 & 7,89 & 0,07 & Valid & 26 \\
\hline & P14 & 0,70 & 10,51 & 0,07 & Valid & 48 \\
\hline & P17 & 0,60 & 6,94 & 0,09 & Valid & 36 \\
\hline \multirow{7}{*}{$\begin{array}{c}\text { Spontanitas } \\
\text { P-value }=0,075 ; \\
\chi 2=11,45 ; \text { RMSEA }=0,071\end{array}$} & P5 & 0,55 & 7,35 & 0,07 & Valid & 30 \\
\hline & P7 & 0,34 & 4,33 & 0,08 & Valid & 11 \\
\hline & P8 & 0,33 & 4,32 & 0,08 & Valid & 11 \\
\hline & P11 & 0,72 & 7,81 & 0,09 & Valid & 52 \\
\hline & P19 & 0,58 & 7,48 & 0,08 & Valid & 33 \\
\hline & P22 & 0,88 & 10,71 & 0,08 & Valid & 78 \\
\hline & $\mathrm{P} 23$ & 0,67 & 8,23 & 0,08 & Valid & 44 \\
\hline
\end{tabular}

Jika ditinjau dari struktur butir ternyata hanya P12 dengan loading factor $<0,30$ merupakan butir berisi unsur kejujuran. Contoh butir P12, (a) pasif dan jujur, (b) banyak akal tapi susah sepakat, dan (c) mudah mengerti tapi malas berbuat. Sedangkan butir-butir lainnya, merupakan butir yang tidak mengandung unsur kejujuran. Contoh butir P19, (a) konservatif tapi religious. (b) kaku tapi cepat mengerti. (c) pembohong tapi percaya diri.

Jika ditinjau dari konstribusi butir terhadap indikator, terlihat butir P2, P6, P22 dengan $\mathrm{R}^{2}=100 \%$, $100 \%, 78 \%$ merupakan butir dengan konstribusi paling besar terhadap indikator fleksibilitas, keberanian berbeda, spontanitas.

\section{KESIMPULAN DAN SARAN}

\section{Kesimpulan}

Pengujian validitas konstruk Tes Potensi Manajerial berdasarkan validitas butir dengan metode Factor Analysis menghasilkan 11 indikator dengan jumlah 50 butir valid dari 3 konstruk yaitu kognitif, metakognitif dan kreativitas.

Ketika pertama kali diuji Tes Potensi Manajerial menghasilkan 14 indikator, 35 butir valid dari 2 konstruk yaitu kognitif dan metakognitif (Idulfilastri 2012). Dengan berkurangnya jumlah indikator menjadi 11 indikator tidak mengubah konsep teori dari tes. Karena menurut Kaplan \& Saccuzoo (2001), indikator merupakan indikasi-indikasi yang menjelaskan dan menjabarkan konstruk secara operasional. Di sisi lain, penelitian ini telah membuktikan bahwa Tes Potensi Manajerial dibangun oleh 3 konstruk sesuai dengan konsep teoritis tes.

\section{Saran}


Penelitian ini merupakan tahap awal menguji Tes Potensi Manajerial di industri spesifik yaitu industri otomotof. Oleh karena itu perlu dilanjutkan penelitian di industri lainnya untuk memperkuat hasil penelitian ini bahwa tes dibangun oleh 3 konstruk yaitu kognitif, metakognitif dan kreativitas. Mengingat setiap bisnis mempunyai karakteritik berbeda apakah akan mempengaruhi terhadap konstruk tes.

Pengujian konstruk Tes Potensi Manajerial berdasarkan validitas butir ini, disarankan dilanjutkan dengan pengujian Tes Potensi Manajerial berdasarkan validitas konstruk (Hair, et al., 2006; Young \& Pearce, 2013; Tarka, 2018). Tujuannya untuk membuktikan apakah benar bahwa tes dibangun oleh 3 konstruk yaitu kognitif, metakognitif dan kreativitas. Metode yang disarankan menggunakan CFA second order atau CFA first order dengan skor komposit setiap indikator.

Telah dibuktikan bahwa Tes Potensi Manajerial bersifat prediktif terhadap kompetensi pencapaian target, penyampaian gagasan, pemecahan masalah dan pengambilan keputusan, keberhasilan karir (Idulfilastri, 2012). Disarankan penelitian ini dilanjutkan dengan pengujian model struktural menggunakan SEM (Kaplan, 2009; Maat, Adnan, Abdullah, Ahmad \& Puteh, 2015).

Jika akan dilakukan pengembangan tes berikutnya, disarankan butir-butir yang berkonstribusi tinggi dari hasil penelitian ini dijadikan sebagai anchor item yaitu butir-butir yang menghubungkan antara satu tes dengan tes pengembangan lainnya (Joreskog \& Sorbom, 2001; Kaplan, 2009).

\section{Ucapan Terima Kasih (Acknowledgement)}

Penulis mengucapkan terima kasih kepada Prof. Dali S. Naga yang telah bersedia memberikan masukan terhadap hasil pengujian Tes Potensi Manajerial ini. Penulis juga mengucapkan terima kasih kepada pihak industri otomotif yang telah membantu penelitian kami.

\section{REFERENSI}

Cohen, RJ., Swerdlik. ME. (2005). Psychological testing and assessment: An introduction to tests and measurement. Sixth Edition. New York: McGraw-Hill.

Furr, RM., Bacharach, VR. (2014). Psychometrics: An Introduction. Second Edition. London: Sage Publications, Inc.

Gagne, F. (2008). Building gifts into talent: Overview of the DMGT, University Quebec, Montreal, Canada.

Hair, J.F., Black, W.C., Babin, B.J., Anderson, R.E., Tatham, R.L. (2006). Multivariate data analysis. Sixth Edition. New Jersey: Pearson Prentice Hall, Pearson Education International.

Hashmi, MA., Zeeshan, A., Saleem, M., Akbar, RA. (2012). Development and validation of an aptitude test for secondary school mathematic students. Bulletin of Education and Research, 34(1), 65-76

Idulfilastri, RM. (2012) Tes Potensi Manajerial Berbasis Ranah Kognitif Untuk Memprediksi Kinerja Calon Karyawan. Disertasi, Fakultas Psikologi Universitas Indonesia, Depok.

Joreskog, K., Sorbom, D. (2001). LISREL 8: Users reference guide. Scientific Software International, Chicago.

Kaplan, D. (2009). Structural equation modeling: Foundation and extensions. California: SAGE Publication Inc.

Kaplan, RM., Saccuzzo DP. (2001). Psychological testing: principles, applications, and issues. Fiith Edition, California: Wardsworth Thomson Learning Inc.

Kellow, JT. (2005). Exploratory factor analysis in two measurement journals: Hegemony by default. Journal of Modern Applied Statistical Methods, 4(1), 283-287.

Knutson, DJ. (2014). Management Aptitude of Enterpreneurs. New York: Routledge. 
Maat, SM., Adnan M., Abdullah, MFNL., Ahmad, CNC., Puteh, M. (2015). Confirmatory factor analysis of learning environment instrument among high performance school students. Creative Education, 6, 640-646. Diunduh dari http://www.scirp.org/journal/ce. http://dx.doi.org/10.4236/ce.2015.66063

Mankar, J. \& Chavan, D. (2013). Differential aptitude testing of youth. International Journal of Scientific and Research Publications, 3(7), 1-6. Diunduh dari http://www.ijsrp.org/researchpaper-0713.php?rp=P191459

Panjaitan, R.L., Irawati, R., Sujana, A., Hanifah, N., Djuanda, D. (2018). Item valditity vs. item discriminantion index: A redundancy? Journal of Physics: Conference Series, 983, 1-5. doi : 10.1088/1742-6596/983/1/012101

Sijtsma, K. (2009). Reliability Beyond Theory and Into Practice. Psychometrika, 74(1), 169-173.

Tarka, P. (2018). An overview of structural equation modeling: Its beginnings, historical development, usefulness and controversies in the social sciences. Qual Quant, 52, 313-354. Diunduh dari https://doi.org/10.1007/s11135-017-0469-8.

Watson, G., Glaser, E.M., (2008). Watson-Glaser: Critical thinking appraisal. Short Form Manual. Pearson Education.

Wigboldus, DHJ. \& Dotsch, R. (2016). Encourage Playing With Data And Discourage Questionable Reporting Practices. Psychometrika, 81(1), 27-32.

Wijanto, SH. (2008). Structural Equation Modelling dengan LISREL 8.8: Konsep dan Tutorial. Graha Ilmu. Yogyakarta.

Yong, AG. \& Pearce, S. (2013). A beginner's guide to factor analysis: focusing on explaratory factor analysis. Tutorials in Quantitative Methods for Psychology, 9(2), 79-94. 